engaged:in research on the subject of the Diatessaron. Mr Burkitt, in his edition of the old Syriac Gospels has set us a model of the method to be followed in such investigations, and has supplied us with a number of clues which make it comparatively easy to detect whether a Syriac writer who quotes to any extent from the Gospels is using the Peshitta, syr. vt., or the Diatessaron. With the help of his book I think it can easily be shewn that Jacob of Serug used both Pesh. and Diat. very freely, in the way no doubt that fourth-century writers used syr. vt. and Diat. It is improbable that syr. vt. survived in use so long after Rabbula's revision; so that, when Jacob gives us a reading which differs from Pesh. and yet appears not to be due merely to. metrical considerations or to paraphrase, we may generally conclude that it is drawn from a copy of the Diatessaron, whether or no it agrees with the Old Syriac.

R. H. Connolly.

\title{
ON AN APOSTOLIC TRADITION THAT CHRIST WAS BAPTIZED IN 46 AND CRUCIFIED UNDER NERO.
}

\section{Victorinus, Alexander of Jerusalem and the 'exemplaria apostolorum'.}

There is a well-known puzzle in St Irenaeus, where that Father declares that our Lord reached an age between 40 and 50 , resting his statement on an appeal to 'the Presbyters who had seen John face to face'. It cannot be doubted that it is to the book of Papias that St Irenaeus is referring, and I hope to shew in a second article that it is not impossible to discover what Papias really said upon the subject, and how St Irenaeus's mistake arose.

But before directly approaching this point, it is necessary to deal with the support which St Irenaeus's view may be supposed to obtain from certain consular dates reported in a fragment published by Muratori, by which the birth of Christ is placed in A.D. 9, His baptism in 46 , His death in 58 , thus implying an age of 49 years. The authority for these dates is given as the exemplaria apostolorum, which might well stand for the Exegeses of Papias. Von Dobschütz has preferred rather to refer their tradition to the first century, and to represent it as a rival in antiquity and authority to the chronology given by St Luke. I hope the present article will establish that it belongs rather to the opening 
years of the third century. If this be admitted, the way will be cleared for the consideration of St Irenaeus's blunder and its probable explanation.

In the April number of this JournaL (1906) Dom Morin published a version of the fragment to which I have referred.' A comparison of the new text with that of Muratori (as corrected by von Dobschutz) will show that my confrère's discovery is of great interest. I place them side by side. The italicized letters are rubricated in the Milanese MS

Dom Morin's Fragment.

Hieronymus.

In commentariis Victorinı inter cetera haec etiam scripta reperi quod in membranis Alexandri episcopi qui futt in ierusalem. quod transcripsit manu propria de exemplaribus apostolorum viii $\mathrm{kl}$. ian. natus est dominus iesus $\chi \rho \sigma$ suplicio et cromatio consulibus. Baptizatus viri. id. ian. valerio et asiatico consulibus. Passus vero viii kl. apr. nerone tercio. et valerıo messula consulibus. Surexit vi $\mathrm{kl}$. apr. consulibus suprascruptis.

Supputatur quippe eodem die dominum fuisse conceptum quo et resurrexit. feria vi. anuncratus. fer. $i$. natus feria v. baptizatus. fer, vi, passus A die nativitatis domini usque ad passionem ipsius anni. xxxil. menses. iii.; dies .xi.
Muratori's Fragment.

In commentariis uictorini inter plurima hec etiam scripta reperimus invenimus in membranis alexandi $\overrightarrow{\text { epi qui }}$ fuit in hyerusale quod transcripsit manu sua de exemplaribus apostolorum ita

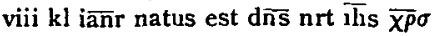
sulpitio et camerino consulis et baptizatus est viiz iđ iañ valeriano . et asiatico cons. passus est $x$. ki a a $\bar{p}$ nerone $u i$ et ualerio. mesala conss resurrexit. vnt $\mathrm{k} \overline{\mathrm{l}}$ ' ap $\overline{\mathrm{l}}$ coñsss supra scriptis. ascendit in celos $v$ nō maias post dies $x l$. coñss supra scriptıs. iohannis baptısta nascitur viii $\mathrm{kI}$, iul et crrcumciditur $k l$. iul ad mariam uero locutus est angelos vini $\overline{\mathrm{K}}$ apl sexto iam conceptionis mense $r$ elisabeth habere dicens ex quo supputatur eodem die dominum fuisse conceptum quo et resurrexit. Amen.

The additions in the Muratorian version do not commend themselves as ancient. It was easy to calculate the date of the Ascension and to add it in. The feast of St John Baptist and its octave were

1 The fragment was originally published by Muratori at the end of an anonymous Liber de Computo, where it occurs in a Bobbio MS (Ambros. H 150 inf. oltm $70 \mathrm{~S}$ ), in his Analecia vol. nii (reprinted in $P . L .129$, col, 1369). It was inserted by Routh in his Reliquace. An exact transcript from the MS is given by Von Dobschatz in the appendix to his study, of the Kerygma Petri (T.U. xi, I, 1893) p. I37. The excursus he has devoted to it is very valuable, and I am greatly indebted to it. Dom Morin's fragment is from Cod. 1473 of the University of Padua (J.T.S. April 1906, p. 459). 
somewhat obvious. ${ }^{1}$ The Annunciation on March 25 is presupposed in the shorter version, and in the longer version is out of its place; it should have come first or not at all.

The remaining dates may well be of early origin. March 25th was apparently given for the Annunciation in the Chronicle of Hippolytus, ${ }^{2}$ and December $25^{\text {th }}$ for the Nativity is found in our present text of his commentary on Daniel (iv 23, Bonwetsch, p. 242). January 6th was celebrated as a feast of the Baptism by certain Basilidians in the second century. ${ }^{3}$

As for the dates of the Passion and Resurrection, it is obvious that the Milan MS is right in setting the Resurrection on March 25th, the same day as the Conception. The correction made in the Paduan MS was a natural one, for the Passion on March 25th is found in Tertullian, Hippolytus on Daniel, in the Philocalian Calendar of 336 , the Acts of Pilate, \&c. It became later so common that in the fifth and sixth centuries feasts of the Passion and Resurrection were kept in Gaul on March 25th and $27^{\text {th }}$, as we find in the Hieronymian Martyrology. Lactantius, a contemporary of Victorinus, gives the $23^{\text {rd }}$ for the date of the Passion, as in the true reading of the fragment."

Further down, quippe is evidently the right version, ex quo being substituted when the date of the Annunciation was no longer presupposed, but actually stated.

The commencement is more puzzling. The untranslateable version of Dom Morin's Codex is perhaps a mere blunder. If the other form is the original, then we have a verbal citation of what Alexander of Jerusalem wrote. This will extend, doubtless, to the days of the week of Dom Morin's version, but will not include the last sentence of all, for the months and days there given are obviously inconsistent with the calculations which have preceded. There are four sources to be considered, the excerptor, Victorinus of Pettau, Alexander of Jerusalem, and the exemplaria apostolorum. How much comes from the last source we cannot tell as yet; I distinguish the other three in the following conjectural restoration of the fragment :

' The feast of St John Baptist is first found in St Augustine's sermons, and it is not in the Philocalian Calendar nor in that of Polemaeus Silvius (Duchesne, Origines du Culte Chreitien $3^{\text {rd }}$ ed. 1903 , p. 27I). Duchesne points out that June 24 is a Latzn calculation (according to Luke $\mathrm{i}_{36}$ ) of exactly six months before December 25 , i.e. viii $\mathrm{kl}$. Jul. -viii kl. Jan.; a Greek would have made it June 25.

${ }_{2}$ March 28 is given for the Nativity in the pseudo-Cyprianic De Pascha computus of A. D. 243. December 25 is given in the Phulocalian Calendar.

s Clem. Al. Strom. i 2 I, pp. 407,408 (Potter).

- Tiberius XV, consulship of the two Gemini, $x$ kal. Apr. (Divin. Inst. iv Io, and De Mort. Persecut, 2). 
In commentariis Victorini inter plurima haec etiam scripta reperimus :

- Invenimus in membranis Alexandri episcopi qui fuit in Hierusalem quod transcripsit manu sua de exemplaribus apostolorum :

"viij kal. ian. natus est dominus noster Iesus Christus, Sulpitio et Camerino coss.

et baptizatus est viij id. ian , Valeriano et Asiatico coss., passus est $x$ kal. Apr., Nerone III et Valerio Messala coss., surrexit vij kal. Apr., coss. supra scriptis

(supputatur quippe eodem die dominum fuisse conceptum quo et resurrexit).

Feria vi annuntiatus, feria i natus, feria v baptizatus, feria vi passus." '

A die natıvitatis domini usque ad passionem ipsius anni xxxij, menses iij, dies xj.

\section{The Evidence of St Epiphanius.}

Of the strange consular dates Herr von Dobschutz has shewn that one is also given by St Epiphanius and that two are repeated by George the Syncellus.

We will first take St Epiphanius, Haer. 5 I. 29. It is universally recognized that his arguments against the 5 Ist heresy are founded on the lost book of Hippolytus in defence of the fourth Gospel and the Apocalypse. ${ }^{1}$

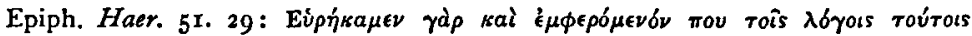

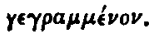

\section{${ }^{2}$ (Petavius) (Dindorf)}

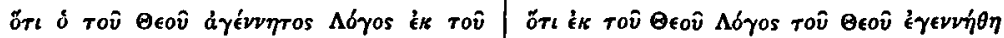

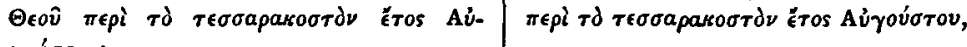

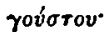

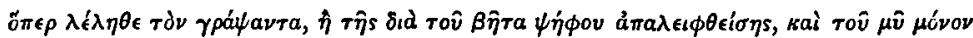

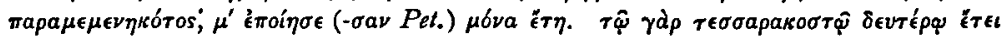

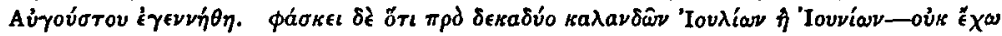

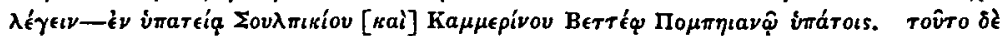

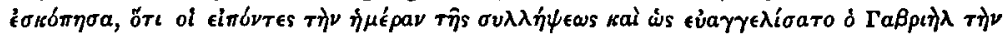

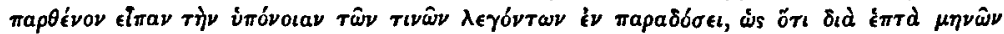

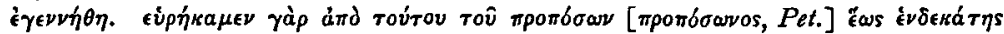

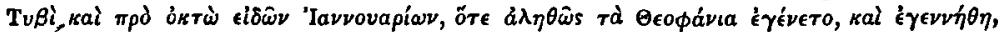

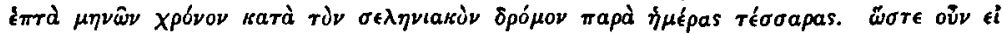

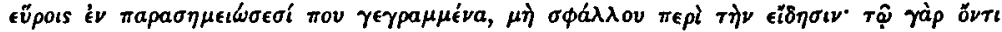

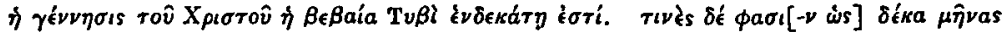

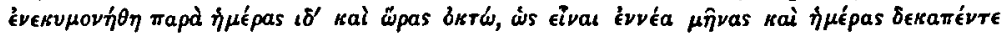

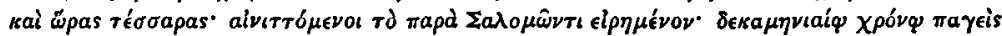
'v aïratı (Wisd. vii 2).

1 Zahn G.K. i 227 and ii 970, note 8; Harnack Chronol. ii 227. The last chapter Heresy $5^{\mathrm{I}}$ shews an unmistakeable connexion with Hippolytus's Heads against Gaius in defence of the Apocalypse.

2 In Dindorf's text the want of the article with $\Lambda$ ó ${ }^{\prime}$ s is unbearable. In that of Petavius the verb is wanting. Further down we find it assumed that the date

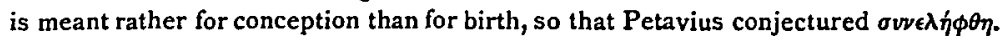
But the following clause anyhow gives '́ $\gamma \in v \nu \eta \dot{\theta} \eta$.

VOL, VIII. 
Epiphanius has a way of quoting his authorities word for word, regardless of sense. A well-known instance of such carelessness is found in Haer. 27. 6, where we are told that 'a certain Marcellina came to us (!) in the days of Pope Anicetus', a sentence which was evidently written at Rome in the second century. It is probable that we

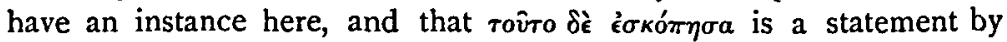
Hippolytus. It is evident that neither June 2oth to January 6th (200 days) nor May 2 Ist to January 6th (230 days) make seven lunar months minus 4 days $\left(29 \frac{1}{2} \times 7-4=202 \frac{1}{2}\right) .^{1}$ But Hippolytus placed

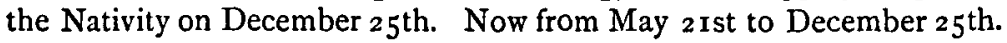
is exactly seven calendar months plus 4 days. If Epiphanius found this in Hippolytus, but understood January 6th to be meant and not December $25^{\text {th }}$ (i.e. viii $k l$. Ian. for viii id. Ian.), it would be natural for him to reduce the 230 days by suggesting xii $k l$. Iul. for xii $k l$. Iun.; and then to get the calculation right all but $2 \frac{1}{2}$ days by taking the months to be lunar months, and by subtracting instead of adding the 'all but four days'.

We are further told that others said that Christ was ro months less 14 days and 8 hours in the womb. As this is said to be 9 months I 5 days and 4 hours, a lunar month of $29 \frac{1}{2}$ days is assumed. But the calculation is evidently based on a rough calculation by calendar months, and comes not from Hippolytus but from the authority from whom St Epiphanius has borrowed his own system. For from March 2 Ist (St Epiphanius's date for the Resurrection) to Jan. 6th is just 10 months minus $14 \frac{1}{2}$ days. We gather that here again the Resurrection is placed on the same day as the Annunciation, in order to give an exact number of years for the abiding of the Word among men.

In fine, it appears that Epiphanius attributes to Hippolytus (for we have no reason to assume that he is using a different source here from the source he uses throughout the section on the Alogi) the statement that Christ was conceived in the 4 oth year of Augustus, on 2Ist May, in the consulship of Sulpicius [and] Camerinus and Vettius Pompeianus, and that he was, according to a tradition, born seven months and four days later on the $25^{\text {th }}$ December. This does not at all accord with the dates given by Hippolytus in his Chronicle and in his Commentary on Daniel. We shall presently have to consider how to explain this divergence.

\section{The Evidence of George Syncellus.}

We have now to discuss the witness of George the Syncellus. It is particularly important, because this Byzantine writer, a contemporary of

1 What $\pi \rho \circ \pi \delta \omega \nu$ may mean I have no idea. Dobschatz suggests a corruption of propasitio or some such word. 
the seventh council, had before him the chronological systems of Eusebius and of Panodorus, but preferred to them that of Annianus, as resting on better authority. He explains (ed. Dindorf p. 596) that the angel Gabriel came to Mary as the 24th of March (the last day. of the year of the world 5500) was passing into the 25th of March, $55^{\circ} \mathrm{I}$. The conception lasted 275 days, up to the $24^{\text {th }}$ of December completed, and on the $25^{\text {th }}$ Jesus Christ was born.

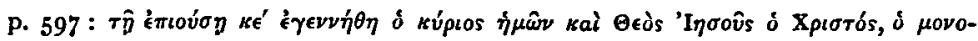

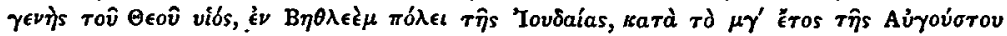

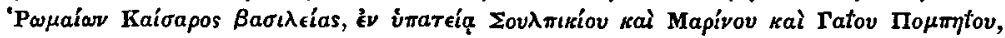

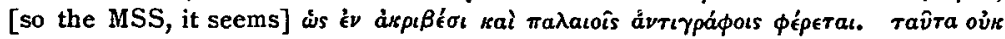

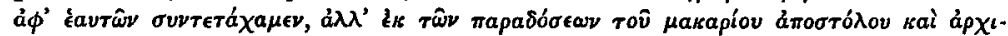

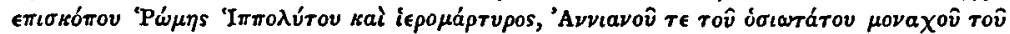

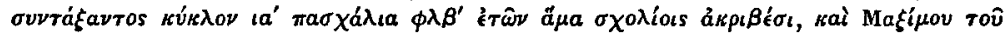

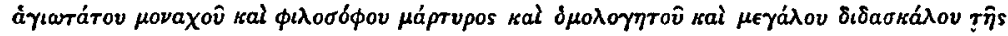
غ $\kappa \kappa \lambda \lambda$ oías.

Here we find again the impossible consulship for the Nativity, with the dates March 25 and December 25. The source is Annianus, whose chronology went up to the year 4I 2. Annianus rested upon Hippolytus, whom he calls an 'apostle'. St Maximus Confessor appears simply to have used Annianus. Von Dobschütz ${ }^{1}$ cites the Vita Euthymii and Vita Sabbae by Cyril of Scythopolis as declaring that the sources of

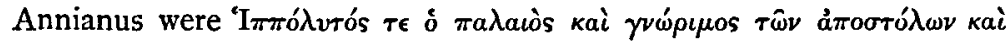

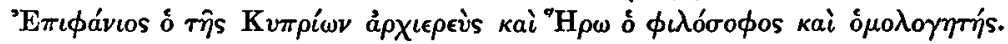
Who the last personage may be is uncertain. 'Philosopher and confessor' is like what is said of St Maximus. ${ }^{2}$ The most curious fact is the appeal to Hippolytus, who was apparently the source used by Epiphanius.

A little further on Syncellus has the Passion in the year 5533, Tiberius 19 :

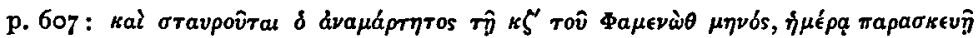

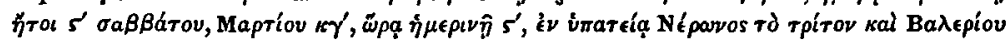

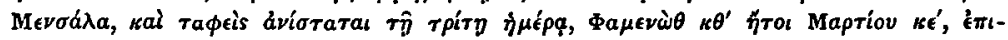

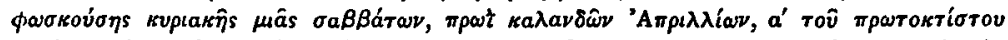

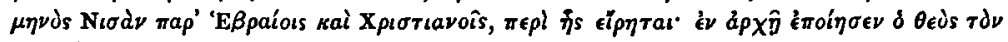

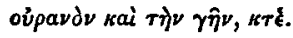

Here we find the consulship for the Passion, the dates March 23 and 25 , Sunday, with the addition of the statement that the creation of the world began on March 25. This was from Annianus, and Syncellus is very fond of repeating the statement. ${ }^{3}$

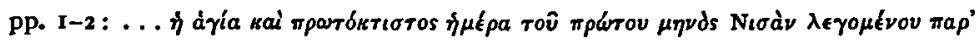

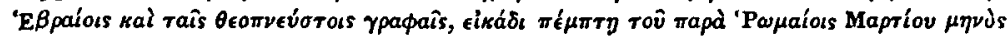

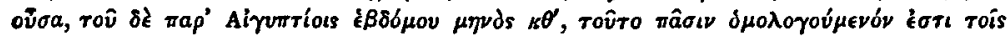

$$
\text { 1.c. p. } 146 \text {. }
$$

2 See von Dobschütz's note, p. 146.

\section{See Gelzer Julius Africanus ii 248.}

Q q 2 


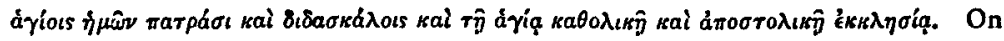
this day were also the Annunciation and the Resurrection.

Again, p. 590, he repeats that he had said at the beginning of his

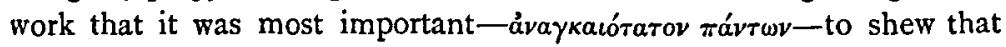
the Annunciation and the Resurrection took place on March 25 like

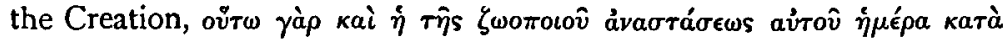

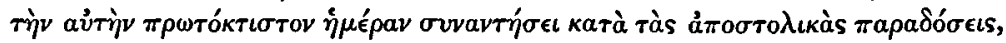

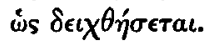

Yet again, p. 592, he finds fault with Panodorus for having put the Incarnation in the year 5493 ; whereas Syncellus himself has adhered to the Divine Scriptures and the traditions of the Apostles : $\dot{\eta} \mu \epsilon \hat{\imath} \delta \delta \dot{\epsilon} \tau \hat{\varphi}$

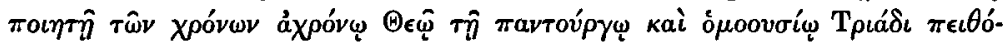

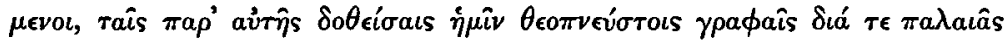

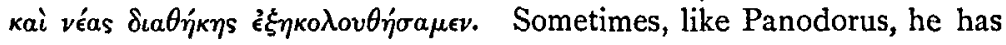
agreed with non-Christian writers, but sometimes has found ávanintovoav

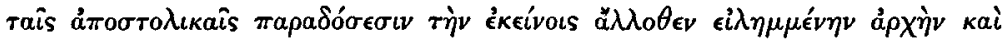

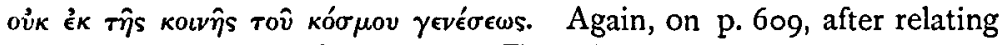
that the Ascension took place on a Thursday, May 3, he resumes :

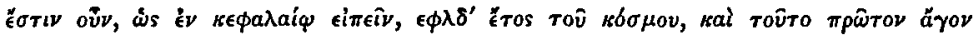

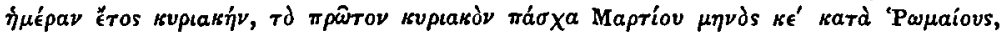

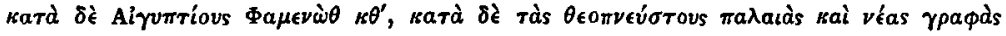

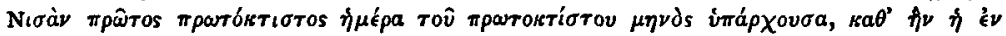

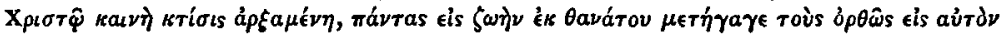

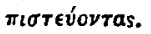

\section{The Origin of the Consular Dates.}

It was remarked by Mommsen (ap. von Dobschütz, p. 143) that the double names of the consuls are given, whereas in late writers one name for each consul is deemed sufficient (e.g. in Epiphanius, 51. 22, the Excerpta Barbari, the Consularia Ravennatia, \&c.). The corruptions in the names are evidently due to transcribers.

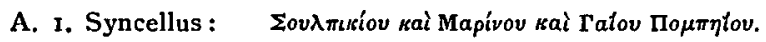

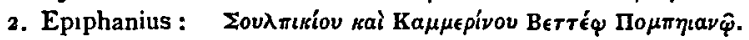

3. Morin's frag. : Suplicio et Cromatio.

4. Murat.'s frag.: Sulpitio et Camerino.

5. Correctly: Q. Sulpicio Camerino et C. Poppaeo Sabino.

Evidently C. Pompeius was the easy error of a copyist for C. Pop-

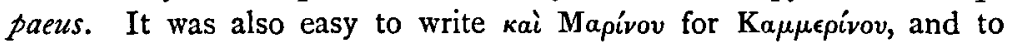
correct into кai Ka $\alpha \mu \epsilon$ ívov. The calculator had before him the correct version Sulpicio Camerino et C. Poppaeo, the consuls for A. D. 9. But it is important to notice how clearly the identity of source for all our authorities is proved by the common error of et after Sulpitius.

B. Valerio (Valeriano) et Asiatico consulibus is the datum of the Latin fragments. It was owing to the et interpolated between the 
former consuls' names in A that the second consul's name was left out in the Latin. We may presume that the source gave both consuls in B also, viz. Valerius Asiaticus II, Marcus Junius Silanus = A. D. 46.

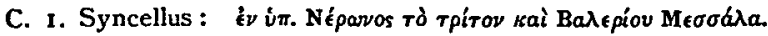
2. Latin frag. : Nerone III et Valerio Messala coss.

Here there is no corruption worth mentioning, and von Dobschütz has pointed out that the correct double name is otherwise only known from Tacitus $A n n$. xiii 34, since Idatius and all others give Messala Corvinus or simply Messala for A. D. 58 .

We must conclude that the calculator of the consulships had before him a perfectly accurate and trustworthy list.

How did he arrive at choosing these particular consulships? Did he really believe that Christ was born as late as A. D. 9, was baptized at the age of 37 , and crucified at 49 ? If he actually supposed this, it is surely remarkable that there is no sign of such a view in the authors who copied and preserved for us his consular dates.

We naturally presume that a person who was anxious to determine the consulships was a Western, and that one who gave the days of the month by kalends and ides was a Western, for in the East it was more usual to speak of the $25^{\text {th }}$ of March than of viii kal. April. He will have written in Greek, however, as he was used by the Greek writers, Alexander, Annianus, and Epiphanius. One naturally infers a Roman writer, who wrote in Greek and whose writings were read in the East. These hypotheses tally extremely well with the repeated testimonies that Hippolytus was the man. Again, the accuracy of the list of consuls which he employed suits a Roman source. We shall presently consider whether Hippolytus could have perpetrated these dates. At present let us assume that the calculator was really a Roman writer of the beginning of the third century. On what chronology will he base his calculations? We are supposing him to be earlier than Africanus (222) and later than Tertullian's Adversus Iudaeos (c. 197).' The chronology of the careless African was much admired at a far later date. St Jerome copied it out, without noticing its absurdities, and Ambrosiaster thought it admirable. ${ }^{2}$ Our Roman author would use it without hesitation.

Tertullan is obliged to compress the period between the birth of Christ (Augustus XLI) and the siege of Jerusalem (Vespasian I) into $7 \frac{1}{2}$ weeks of years, i. e. $52 \frac{1}{2}$ years, for he is bent upon proving to the Jews the fulfilment of the prophecy of Daniel, and he makes the 62 weeks end at the birth of Christ, while the midst of the 7 oth week coincides

I On the date of $A d v$. Iudaeos see Harnack Chronol. ii 288-92, whose conclusion seems to be sound.

${ }^{2}$ Jerome Comm. in Dantel cap. ix, Vallarsi v p. 691, Ambrst. Quaest. in Vet. Test. 44 


\section{THE JOURNAL OF THEOLOGICAL STUDIES}

with the commencement of the Jewish war. For this purpose he omits the whole reign of Claudius, and shortens that of Nero, curtailing the whole period by $17 \frac{1}{2}$ years ! From the accession of Tiberius, August 19, A. D. I4, to that of Vespasian, July I, A.D. 69 , is nearly 55 years; Tertullian allows only $37 \frac{1}{2} .^{1}$

$\dot{x}$. Lèt us suppose our chronologist to have before him an accurate list of consulships and Tertullian's treatise against the Jews. He wishes to calculate the date of the baptism of Christ, which took place (he knew from St Luke) when he was $3^{\circ}$ years old. He could count 30 years forward from the Nativity, if he had already determined the consuls for that event. But it was simpler to count back $22 \frac{1}{2}$ consulships from the first year of Vespasian, for 30 from $5^{2 \frac{1}{2}}$ leaves $22 \frac{1}{2}$. Now the twenty-third consulship back from Vespasian I (=A.D. 69) is that of Valerius Asiaticus II (= A. D. 46).

1 Tertullian's chronology, Adv. Iud. 8, is as follows (I give the true periods in brackets, and to the total of these $I$ have added in the 13 years 8 months 19 days of Claudius) :

\begin{tabular}{|c|c|c|c|}
\hline $\begin{array}{l}\text { Augustus } \\
\text { Tiberius } \\
\text { Gaius } \\
\text { Nero }\end{array}$ & $\begin{array}{l}\text { 15. 0. } 0 \\
\text { 22.7. } 20(22.6 .5) \\
\text { 3.8. 13 (3. 10. 8) } \\
9.9 .13(13.7 .27)\end{array}$ & $\begin{array}{l}\text { Galba } \\
\text { Otho } \\
\text { Vitelıus }\end{array}$ & 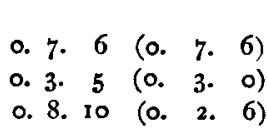 \\
\hline & & Total & $5(69$. 10. 12) \\
\hline
\end{tabular}

There is no reason for doubting the authenticity of this chapter of $A d v$. Iudaeos. On the genuineness of even the later part see Harnack Chronol. ii p. 289. I have spoken elsewhere (Revue Bénéd. April 1902, pp. 156-163) of Tertullian's utter want of the historical sense. With regard to the above list, it is not difficult to conjecture how Claudius may have fallen out. Tertullian seems, from certain coincidences, to have used a list carelessly extracted from Clement's discussion of the jo weeks. The text of Clement (Strom. i 21 , Potter i p. 406) is corrupt, but it is certan that he used an exceedingly good catalogue of Emperors, for some of his numbers are still surprisingly exact, e.g. Vespasian I1. 11. 22 (really 9. I1. 22); Gaius 3. 10. 8 (right); M. Aurelius 19. O. II (19. 0. 10); Commodus 12. 9. I4 (12.9. I5). In Potter's text we find the same figures-13. 8. 28-both for Claudius and for Nero, so that a careless scribe might easily omit one of the names by accident. Again, 28 days are practically a month, so that 13. 9. 0 would be substituted for 13. 8. 28. The iota for the 10 months of Gaius might easily be overlooked. If, then, the scribe copied the names first (omitting Claudius by mistake, on account of the same figures being repeated for Nero), he would have the following figures to fill in : $3.0 .8 ; 13.9 ; 13.9$. So we get :

\begin{tabular}{|c|c|c|c|c|}
\hline \multicolumn{2}{|c|}{ Clement } & cormption & \multicolumn{2}{|c|}{ Tertullian } \\
\hline Gaius & 3. 10. 8 & 3. 8. & Gaius & 3. 8. I 3 \\
\hline $\begin{array}{l}\text { Claudius } \\
\text { Nero }\end{array}$ & $\begin{array}{ll}\text { 3. } & 8.28 \\
3 & 8.28\end{array}$ & $\begin{array}{ll}\text { I3. } & 9 . \\
\text { I3 } & 9 .\end{array}$ & Nero & \\
\hline
\end{tabular}

For Nero 9. 13. 9 was of course impossible, as a year has only 12 months, so that 9. 9. I 3 was an obvious emendation. If this conjectural explanation is true, we can acquit Tertullian of intentionally manipulating the statistics, and the resultant $52 \frac{1}{2}$ years were a piece of good fortune and not a trick! 
Our hypothesis has so far justified itself.

2. To find the consuls for the Nativity he would have to count back $52 \frac{1}{2}$ consulships. This would be too much trouble. We have learnt from St Epiphanius that he dated this event in the 4oth year of Augustus (and not, as Tertullian did, in the 4rst). Now Tertullian joins on his Roman imperial chronology to that of the Ptolemies, thus :

Ptolemaeus annis xxxviii, Cleopatra annis $x x$, mensibus vi. Item adhuc Cleopatra conregnavit Augusto annis xiii, post Cleopatram Augustus aliis annis xlii, nam omnes annı imperii Augusti fuerunt lvi. Videmus autem quoniam quadragesimo et primo anno imperis Augusti, quo post mortem Cleopatrae imperavit, nascitur Christus. Et supervixit idem Augustus, ex quo nascitur Christus, annis xv.

The last sentence gives Tertullian's real meaning, as developed afterwards. The 30 years of Christ at His baptism were made up of I5 years of Augustus and 15 of Tiberius: consequently it was in the 4 Ist of the 56 years of Augustus that Christ was born, i. e. B. c. 2 or 3. But the words I have italicized distinctly state (by a slip of the pen, no doubt) that the $4 \mathrm{I}$ years are to be counted from the death of Cleopatra. Consequently our calculator counts the consulships forward from B. c. $3 \mathrm{r}^{1}$ (death of Cleopatra), and the 4 oth year is A.D. 9, the consulship of Sulpitius Camerinus and C. Poppaeus!

Again we have a perfectly simple explanation of a ridiculous date.

3. To get the date of the Passion our ingenious calculator will have said: There are 43 years of Augustus: from his 4 oth year to the accession of Tiberius are 4 years; from thence to Vespasian are $37 \frac{1}{2}$ years; $37 \frac{1}{2}+4$ are $41 \frac{1}{2}$; if I count back $10 \frac{1}{2}$ years from Vespasian, I shall allow $3^{\mathrm{I}}$ years of life, i. e. one year of ministry. Eleven years back from Vespasian bring us to A. D. 58 , the consulship of Nero III and Valerius Messala. This was shorter than counting forward $3^{\mathrm{I}}$ consulships from that of Camerinus and Poppaeus.

It seems, then, that our chronologist always made his calculations by counting his consulships in the shortest direction. It is therefore the less surprising that he did not trouble to verify his results by counting . the intermediate consulships which intervened between his three consular dates. He believed that he had placed our Lord's baptism in the $15^{\text {th }}$ year of Tiberius at the age of 30 . In reality he had placed it in the 6th year of Claudius at the age of 37 ; the Passion, which should have been in the following year, has got into the reign of Nero, 12 years later, giving the age of 49 ! We shall see presently that he attempted to correct this last result.

1 No date would be better known to a Western writer than this of the battle of Actium, the real line between the Republic and the Empire. 
4. It is plain, I think, that the calculator was using Tertullian, and not Tertullian's source (if indeed he had a source for the completed form of his chronology), for the slip about the death of Cleopatra would hardly have been copied even by a writer so careless as Tertullian. But there is yet one more apparent coincidence about which I am uncertain. Dom Morin's fragment alone concludes with the statement that the whole life of Christ was of $3^{2}$ years, 3 months, and I I days. Obviously this is incompatible with any of the dates which have come before us. Three months and eleven days from December 25 or January 6 land us in April instead of March, and if counted back from March 25 or 21 would bring us to December 14 or 10.

But let us suppose a later corrector, who remarks that 46 or $5^{8} \mathrm{~A}$. D. are impossible dates. He himself follows the Dionysian era, and also notices that the whole reign of Claudius has been omitted. $\mathrm{He}$ takes the earlier date, which gives 46 years, and subtracts from these 46 years the reign of Claudius, viz. 13.8. I9. and the result is 32.3 . I ! Is this merely a most remarkable coincidence? or is there some other way of explaining it?

\section{Hippolytus and the Consular Dates.}

It was pointed out above that the calculator of the consular dates was most likely a Western, a Roman who wrote in Greek, whose writings were honoured in the East, who used an early work of Tertullian. On the other hand Epiphanius seems to be quoting Hippolytus where he cites one of these consular dates, and Annianus definitely refers them to that writer.

And yet at first sight it would seem to be impossible to refer these dates to Hippolytus. It is well known that he placed the Passion on March 25, not 23, in the consulship of the two Gemini. He placed the birth of Christ in the 4 2nd year of Augustus, and could not have given for it the consuls of A. D. 9. He did, however, agree in placing the Annunciation on March 25 and the Nativity on December 25.

But the chronicle of Hippolytus seems to have been about his latest work, as it ended in the $13^{\text {th }}$ year of Alexander Severus, 234, whereas the heads against Gaius, and the defence of the fourth Gospel and of the Apocalypse were perhaps written 30 years earlier. There was therefore plenty of time for Hippolytus to change his mind. ${ }^{1}$

1 For these dates see Harnack Chron. ii 228. Compare this writer's words on p. 230: 'Ein Vergleich der Refutatio mit dem Syntagma lehrt, in welchem Masse Hippolyt seine früheren Darstellungen der Häresıen modifiziert hat, und kann als Warnung gegen die belıebte Methode drenen, einem Autor deshalb eine Schrift abzusprechen, weil sie von einer anderen Schnift desselben Autors in derselben Materie stark abweicht.' 
- It is, however, true that we know the system of Hippolytus also from his Commentary on Daniel, an early work of about the same date as the writings against the Alogi, c. $203-205 .{ }^{1}$ But this crucial passage itself testifies to more than one form of chronology.

The MSS (A B P and the Slavonic version) give the following text (iv 23, Bonwetsch, p. 242):

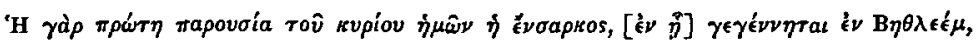

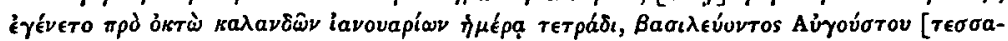

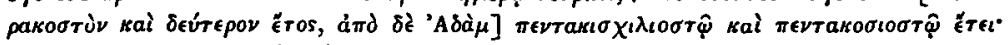

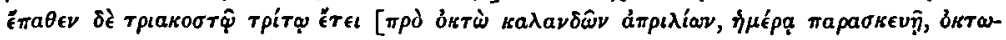

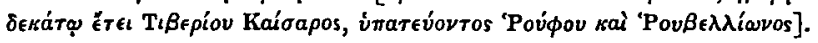

Some disturbance is evidenced by the addition in A of $\pi \rho \grave{\tau} \tau \epsilon \sigma \sigma a ́ p \omega \nu$

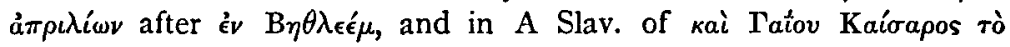

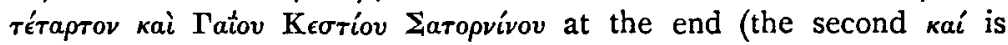
omitted by A).

The Chigi MS (J) on the other hand omits all that I have bracketed, and is supported by Bishop George, the Arabian (died c. 723), who adds at the end 'after his birth'. This simple form runs thus :

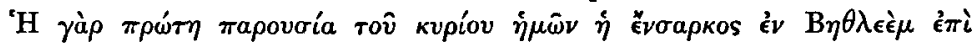
A

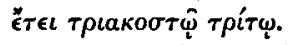

The citation is introduced by George with the words 'The holy Hippolytus, Bishop and martyr, also has said in his fourth lecture on Daniel the Prophet'. It would seem that he found no more in his copy. Consequently Bonwetsch (l. c.) has judged: "Die mitgeteilte von A B P S (vgl. auch Synkellus T X Chronograph) gemeinsam repra-

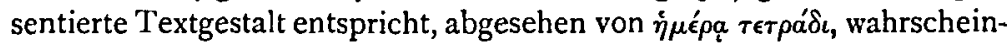
lich der Anschauung Hippolyts (vgl. Salmon, Hermathena, I 892, S. I 78 ), doch durften J und Georg die ursprungliche Lesart darbieten.'

But Harnack seems to be right in pointing out (Chronol. ii 25I) that Hippolytus's later view allowed only one year to the Public Ministry of Christ, and therefore that the thirty-three years in this passage, and also the absurdity of making the consulship of Rufus and Rubellio (i. e. the two Gemini) the eighteenth year of Tiberius, are interpolated; for it is hardly conceivable that an early chronologist who had once held the two or three years' ministry should change back to the traditional but less reasonable one year. But then it follows that the shorter form is not authentic, and that we have but two mangled versions of what Hippolytus originally wrote.

Consequently we conclude that the original reading is lost. It was corrected; it presumably needed correction, and it was, at all events, different from the later system of Hippolytus.

1 Bardenhewer Gesch. ii 533 ; Harnack Chron. ii 250. 
Can we venture to conjecture that the original reading was closely related to the absurd dates attributed to Hippolytus by later writers, dates which were probably given in that writer's defence of the Johannine writings? The Commentary on Daniel seems to have been written about the year 205. The defence of the Johannine writings was but a few years earlier or later. ${ }^{1}$

There is actually some evidence that the conjecture may be safely hazarded. It has been already remarked that the MS A and the Slavonic version of the passage we are discussing give an impossible addition at the end of the paragraph; to the consuls for the Passion

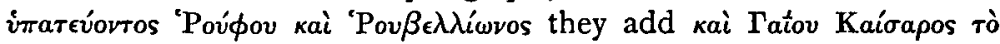

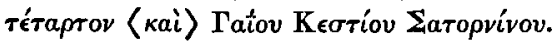

Now in the first place we notice that this is clearly the remains of a rival reading, and (since it is absurd) of an early reading.

Secondly, we notice that while 'Rufus and Rubellio' are given with single names, the earlier reading has just that rare accuracy in giving the double names which we found in the names of the consuls for A. D. 9,46 and 58 . Does it belong to the same calculator? Does it hail from the same accurate list of consuls? Can it be a trace of the original reading as set down by Hippolytus?

Thirdly, we answer all these questions in the affirmative, because this date is calculated on the same system as the others.

The consuls for A. D. $4^{\mathrm{r}}$ were Caius Caesar (Germanicus) IV and Cnaeus Sentius Saturninus. Obviously, this date for the Passion is counted from A.D. 9, i.e. 32 years, or rather $31 \frac{1}{4}$ years. We saw that the date 58 was obtained by counting back, and by an egregious error. We presume that the calculator discovered this, and actually took the trouble to count the consulships forward on his list. Thus we get a correction : $4 \mathrm{I}$ for 58 . It is certainly an improvement.

It would seem probable, therefore, that the original reading in Hippolytus on Daniel gave the birth of Christ in A. D. 9 (either giving the consulship of Sulp. Camerinus, or simply the date Augustus 40) and His Passion in A. D. 4I. Later on Augustus 42 and Rufus and Rubellio were substituted, but fortunately the stupidity of some copyist has preserved for us a part of the original reading.

If this be true, it will appear that the Commentary on Daniel was

1 Harnack thinks the Daniel and the De Antichristo may be placed before the defence of the Apocalypse, since in those works the Apocalypse is freely used, and no suggestion is made that it was rejected by any Christians. But this is not conclusive. It does not seem that the Alogi had a strong following, and there was no reason why Hippolytus should mention their views, especially if he had but now refuted them in a special work. 
published shortly after the Defence of the Johannine writings, and not before; for were it earlier, we should have to assume a yet more primitive text giving the consuls for 58 , and to suppose that the consuls for 4 I were already a correction-an unnecessarily cumbrous hypothesis.

The argument has been somewhat involved, but I think we have found solid grounds for believing that Hippolytus, in his Defence of the fourth Gospel and of the Apocalypse, actually gave the dates attributed to him by Annianus and George the Syncellus, and gave a corrected version of one of them in the first edition of his Commentary on Daniel.

But confirmation is not wanting. Harnack seems to be certainly right in pointing to Epiphanius Haer. $5 \mathrm{I}$. 33, as giving the date of the work of Hippolytus in defence of St John (Chronol. i 376 foll.; ii 228). According to that passage the destruction of Thyatira was prophesied by John, 'but now after 112 years that Church exists and grows'. Presently we hear that 'the time of the Apostles, John and the rest was 93 years after the Saviour's Ascension', ôs jo $\nu$ xóvos $\mu \in \tau \grave{c}$

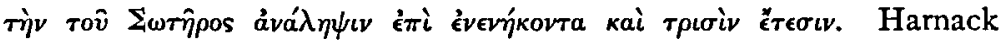
agrees with Dindorf that ${ }^{a} \nu a^{\prime} \lambda \eta \psi \nu \nu$ is wrong, and accepts Petavius's suggestion, $\gamma^{\prime}{ }^{\prime} v \eta \sigma \iota v$. But later Christian chronologists regularly dated from the Incarnation and not from the Nativity, and it is not likely that Hippolytus would have done otherwise. It seems to me therefore that we ought to read $\sigma u ́ \lambda \lambda \eta \psi \iota v$ for ávád $\eta \psi \iota v$, a much easier correction. Harnack adds $93+$ I 12 and gets the date of $204-205$ for the date of the writer.

But Hippolytus did not use the Christian era. We must look further to understand his system. A few pages back, c. 12, Epiphanius has

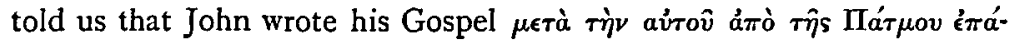

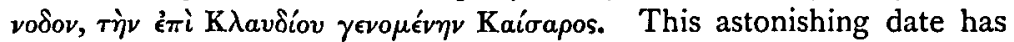
never yet been explained. But it offers no difficulty after our former calculations. Hippolytus followed Tertullian in counting only $52 \frac{1}{2}$ years from the birth of Christ till Vespasian I, and he omitted the reign of Claudius. But he can hardly have altogether ignored so famous an emperor. Where did he insert him? He cannot well have divided Vespasian from his own sons, Titus and Domitian; the earliest place, therefore, for Claudius, is after the Flavian family. Vespasian reigned 9 years, I I months, 22 days; Titus 2. 2. 2 I ; Domitian 15.0 .5 ; in all 27 years. Add these to $52 \frac{1}{2}$, and we see that the accession of Claudius would probably be placed in the 8oth year after the birth of Christ. Claudius would have 14 years, and the 93rd year (that is, the writing of the Apocalypse, presumably) would be the $13^{\text {th }}$ year of Claudius! Thus we at once clear up a hitherto unexplained blunder of Epiphanius, and we confirm our former result, that Hippolytus based his calculations on Tertullian. 
It is clear that in the case of so wild a chronologist as Hippolytus was in his youth we cannot expect to arrive with certainty at the date at which he wrote. From the $13^{\text {th }}$ year of Claudius there would be two years to the accession of Nerva in 96. The 112 years from 94 would bring us to 206 , if we can suppose that Hippolytus was perfectly correct in his chronology from Nerva onwards. But this is quite an unwarrantable assumption, so that Harnack's date of 204-205 is just as probable, and an even larger error is not impossible.

Thus Epiphanius has Hippolytus behind him, and Annianus appealed to him by name. But then, how about Alexander? Here are the words of Eusebius about that bishop's famous library :

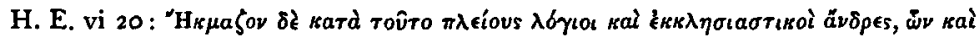

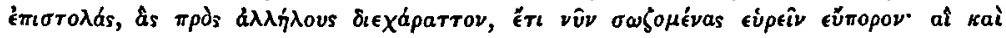

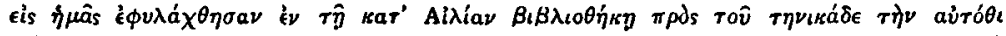

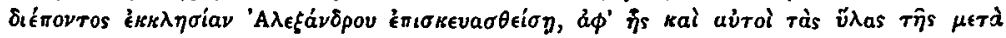

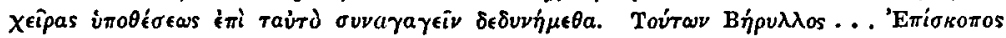

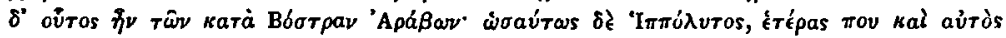

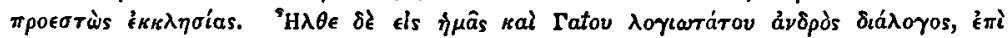

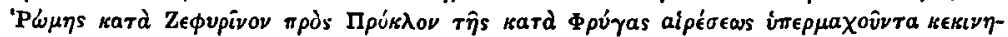

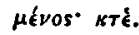

Here we find, side by side, writings of Hippolytus and the Dialogue of Gaius. In chapter 22 Eusebius mentions many writings of Hippo-

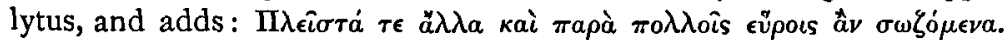
These writings were not historical, and therefore did not much interest Eusebius. But Alexander had evidently made a collection of many of Hippolytus's works. If, therefore, he did not actually possess the whole Defence of the fourth Gospel and Apocalypse, there is nothing astonishing in his having made an extract therefrom in his own hand, and having deposited it in his library.

But it is pretty evident that the subject is not yet exhausted. Hippolytus certainly seens to have appealed to a tradition from the Apostles.

\section{The 'exemplaria apostolorum'.}

Alexander described his authority as exemplaria apostolorum. We have seen that he was using Hippolytus. We must infer that Hippolytus had referred to certain exemplaria apostolorum as his authority.

Now Hippolytus clearly used the Gospels, a list of consuls, and Tertullian Adversus Iudaeos. St Luke told him that Christ was baptized in the ${ }_{1} 5^{\text {th }}$ year of Tiberius at the age of 30 . Tertullian and the list account for the rest of his dates, so far as the years are concerned. 
What days of the month did Hippolytus give? The Latin fragments and Syncellus are at one in giving March 25 for the Annunciation and for the Resurrection, and in declaring that these events were on the same day. But from Epiphanius it would rather seem that Hippolytus had named May 21 for the Annunciation and December 25 for the Nativity, as I shewed above. In this case he cannot have said that the Annunciation and the Resurrection were on the same day of the month, for he cannot possibly have put the Resurrection in May!

But he may well have stated that the Annunciation and the Resurrection took place on the same day of the week. It would be quite natural for Alexander and Annianus to misunderstand this, and to give March 25 for both events, though that was more generally considered to be the date of the Crucifixion.

This conjecture harmonizes well with the witness of Syncellus, who told us repeatedly that the Creation also began on March 25. Now it is clear that the Creation began on a Sunday and that the Resurrection was on Sunday. What more natural than that it should have been said that the Incarnation was also on Sunday - that the true Light came into the world on the day on which the material light had been created?

This is all conjecture. Let us look at Dom Morin's fragment. We find:

Supputatur quippe eodem die dominum fuisse conceptum quo et resurrexit.

As it stands at present, this refers to the preceding statement that the Resurrection took place on March 25. But if Hippolytus really placed the Annunciation on May 2r, it must refer to what follows, and the day of the week will be meant:

\section{Feria vi annuntiatus, feria $i$ natus, feria v baptizatus, feria vi passus.}

In this case we have to alter the text into :

Feria $i$ annuntiatus, feria vi natus.

And this is certainly more natural. Christ comes into the world on Sunday as the Light of the world, and on the same day rises again. $\mathrm{He}$ is born into the world of pain on the same day on which He dies on the Cross.

Let us pursue this hypothesis somewhat further. This identity of the day (of the month) for Creation, Annunciation and .Resurrection is the point which is most definitely referred by Syncellus to the tradition of the Apostles; twice he has referred us to ámorrodıkai

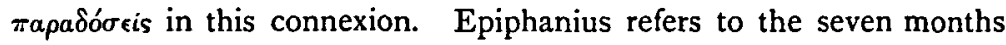
-of conception as $\dot{\epsilon} v \pi a \rho a \delta o ́ \sigma \epsilon t$. Further, Syncellus rests his whole 


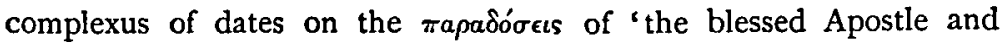
Archbishop of Rome Hippolytus'. We have gathered from the lives of Euthymius and Sabbas that this is an inaccurate reproduction of the words of Annianus, who had called Hippolytus not an Apostle,

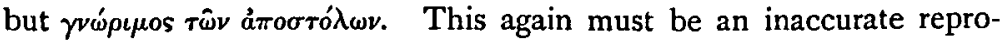
duction of something which Hippolytus said; perhaps he quoted one who had known the apostles; if so, one thinks at once of Clement of Rome (so Irenaeus iii 3 and Epiphanius 27,6), or of Papias, the

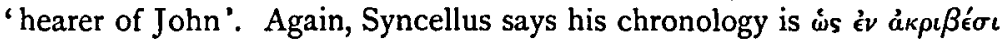

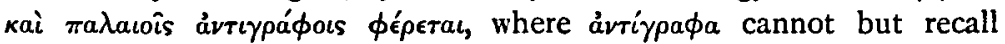
Victorinus's exemplaria.

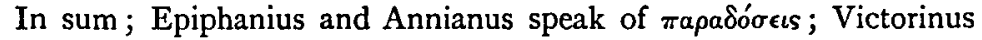
and Annianus speak of exemplaria, àvíipapa; all three speak of apostles, and Annianus in particular supplies the expression $\gamma v \omega$ óp $\iota$ os $\tau \hat{\omega} \nu \grave{a} \pi \circ \sigma \tau o ́ \lambda \omega \nu$.

I think we may at least conclude from this muddle-headed medley that Hippolytus appealed for some part of his chronology to apostolic tradition, from one who had known the apostles. (One might conjecture that the 'accurate and ancient copies' merely referred to his excellent list of consulships.) Now the important point left, beyond what Tertullian and the list of consuls supplied, is the statement that the Annunciation and the Resurrection were on the same day.

I propose, therefore, to assume as a likely hypothesis, that Hippolytus appealed to Papias for the statement that the Annunciation took place on a Sunday, like the creation of light and the Resurrection.

Secondly, it is possible that the days of the week preserved in Dom Morin's fragment were also borrowed from Papias by Hippolytus, if the correction I have suggested is right.

Thirdly, the seven months of conception which Epiphanius calls traditional will perhaps go back to the same source. All the rest of the dates are the invention of Hippolytus himself and have no claim to be 'apostolic'.

Now it so happens that these three points are found together in a short sentence of another fragment of Victorinus. - Long before I noticed this, I had made up my mind on other grounds that this other fragment, and this part of it in particular, was largely based on Papias. I hope to examine this point in another paper, in which we may perhaps recover what Papias really said about the age reached by our Lord.

John Chapman. 